\title{
UPAYA PENINGKATAN PENGETAHUAN IBU MENYUSUI TENTANG ASI DAN LAKTASI DI PUSKESMAS TAMPANG TUMBANG ANJIR KABUPATEN GUNUNG MAS PROVINSI KALIMANTAN TENGAH
}

\author{
Sofia Mawaddah ${ }^{1^{*}}$, Eline Charla Sabatina Bingan ${ }^{1}$ \\ ${ }^{1}$ Jurusan Kebidanan, Poltekkes Kemenkes Palangka Raya, Indonesia \\ "email: sofizline@gmail.com
}

Exclusive breastfeeding is one of the most effective efforts to prevent child mortality. Exclusive breastfeeding is giving breast milk without other food for 6 months. Breast milk is a source of nutrition for babies. Research conducted by Kramer in 2015 showed the growth of the body length of infants aged 9-12 months who received exclusive breastfeeding 6 months faster than those with exclusive breastfeeding for only 3 months, so children who did not get exclusive breastfeeding were at twice the risk of suffering stunting large number of children given exclusive breastfeeding. The purpose of this community service activity is to increase the knowledge and understanding of mothers about proper nutrition for babies aged 0-6 months, namely exclusive breastfeeding for infants, so that mothers are able to improve their understanding of their baby's health problems properly and adequately and be able to implement knowledge about the health of babies and their families in the Gunung Mas area. The targets in this community service activity are mothers who have toddlers in the working area of the Puskesmas in Tumbang Anjir. The implementation of community service activities was carried out in October-November 2018. The place for implementing community service was in 8 posyandu in the working area of Pusang Tumbang Anjir, Gunung Mas Regency, Central Kalimantan Province. Counseling in community service activities uses a tool called leaflets. Evaluation was carried out using the pretest and posttest system.

Keywords: ASI, exclusive, stunting, knowledge, nursing mother

\section{ABSTRAK}

ASI eksklusif merupakan salah satu upaya yang paling efektif untuk mencegah kematian anak. Pemberian ASI eksklusif yaitu memberikan ASI tanpa makanan lainnya selama 6 bulan. ASI adalah sumber nutrisi bagi bayi. Penelitian yang di lakukan oleh Kramer pada tahun 2015 menunjukkan pertumbuhan panjang badan bayi umur 9-12 bulan yang mendapatkan ASI eksklusif 6 bulan lebih cepat dibandingkan dengan bayi yang ASI eksklusif hanya 3 bulan, sehingga anak yang tidak mendapatkan ASI eksklusif berisiko menderita stunting 2 kali lebih besar dari anak yang diberikan ASI eksklusif. Tujuan kegiatan pengabdian masyarakat ini yaitu meningkatam pengetahuan dan pemahaman ibu tentang nutrisi yang tepat bagi bayi usia 0-6 bulan yaitu pemberian ASI eksklusif pada bayi, agar para ibu mampu meningkatkan pemahaman tentang masalah-masalah kesehatan bayinya secara benar dan adekuat serta mampu mengimplementasikan pengetahuan terhadap kesehatan bayi dan keluarganya di wilayah Gunung Mas. Sasaran dalam kegiatan pengabdian masyarakat ini adalah para ibu yang mempunyai balita di wilayah kerja Puskesmas Tampang Tumbang Anjir. Pelaksanaan kegiatan pengabdian masyarakat ini dilaksanakan pada bulan OktoberNovember 2018. Tempat pelaksanaan pengabdian masyarakat ini yaitu di posyandu di 
wilayah kerja Puskesmas Tampang Tumbang Anjir Kabupaten Gunung Mas Provinsi Kalimantan Tengah. Penyuluhan dalam kegiatan pengabdian masyarakat ini menggunakan alat bantu yaitu leaflet. Evaluasi dilakukan dengan menggunakan sistem pretest dan posttest.

Kata kunci : ASI, eksklusif, stunting, pengetahuan, ibu menyusui

\section{PENDAHULUAN}

ASI eksklusif merupakan salah satu upaya yang paling efektif untuk mencegah kematian anak. Pemberian ASI eksklusif yaitu memberikan asi tanpa makanan lainnya selama 6 bulan pertama. Manfaat memberikan ASI eksklusif kepada bayi adalah untuk mengurangi berbagai jenis penyakit ketika tumbuh dewasa. ${ }^{1}$ Pada sebuah penelitian ditemukan bahwa anak yang disusui pada saat anakanak dengan ASI eksklusif maka akan mengurangi berbagai jenis penyakit seperti obesitas, hipertensi dan diabetes melitus tipe 2. ASI adalah sumber nutrisi bagi bayi. Komposisi yang terkandung di dalam ASI menunjang tumbuh kembang bayi serta memiliki antibodi alami yang dapat membantu dalam mencegah infeksi dan gangguan kesehatan pada bayi. ${ }^{2}$ ASI merupakan nutrisi yang lengkap yang dapat memberikan dukungan untuk pertumbuhan, kesehatan, imunitas dan perkembangan bayi. ${ }^{3}$ Pemberian ASI kepada bayi memberikan kontribusi pada status gizi dan kesehatan bayi.

Semua zat gizi yang dibutuhkan bayi pada enam bulan pertama kehidupannya dapat dipenuhi dari ASI, dan ASI dapat memenuhi setengah dari kebutuhan zat gizi bayi umur 7-12 bulan. ${ }^{4}$ Pada tahun kedua kehidupan bayi, ASI menyumbang sepertiga zat gizi yang dibutuhkan. Tidak diragukan lagi, bahwa ASI mengandung zat imunitas yang melindungi bayi dari penyakit infeksi. Efek perlindungan tersebut lebih besar pada enam bulan pertama umur bayi.Pemberian ASI juga berhubungan dengan pertumbuhan panjang badan anak. ${ }^{5}$ Durasi menyusui positif berhubungan dengan pertumbuhan panjang, semakin lama anak-anak disusui, semakin cepat mereka tumbuh baik pada kedua dan tahun ketiga kehidupan. Penelitian Sri Indarawati (2013) menunjukkan pertumbuhan panjang badan bayi umur $9-12$ bulan yang mendapat ASI eksklusif 6 bulan, lebih cepat dibandingkan dengan bayi ASI eksklusif 3 bulan (perbedaan panjang badan $0,9 \mathrm{~mm} / \mathrm{bulan}$ ). ${ }^{6}$

\section{METODE}

Pengabdian masyarakat dilakukan di posyandu puskesmas Tampang Tumbang Anjir Kabupaten Gunung Mas Provinsi Kalimantan Tengah dengan jumlah responden 20 ibu mempunyai balita. Evaluasi kegiatan pengabdian masyarakat ini menggunakan metode pretest dan posttest. Para ibu diberikan soal pretest sebelum penyuluhan, setelah penyuluhan para ibu diberikan soal yang sama dengan soal pretest. Lalu, dinilai pengetahuan ibu sebelum dan sesudah diberikan penyuluhan. Alat bantu saat penyuluhan yaitu leafleat tentang ASI eksklusif. Bentuk soal yang diberikan yaitu soal pilihan ganda tentang ASI.

\section{HASIL DAN PEMBAHASAN}

Tabel 1.Pengetahuan Ibu Menyusui Tentang ASI dan Laktasi

\begin{tabular}{lllll}
\hline Pengetahuan & \multicolumn{2}{c}{ Pre Test } & \multicolumn{2}{c}{ Post Test } \\
& $\mathrm{N}$ & $\%$ & $\mathrm{~N}$ & $\%$ \\
\hline Baik & 5 & 25 & 15 & 75 \\
Cukup & 15 & 75 & 5 & 25 \\
\hline Jumlah & 20 & 100 & 20 & 100 \\
\hline
\end{tabular}

Dari tabel 1 didapatkan hasil pengetahun ibu saat dilakukan prestest sebelum penyuluhan yaitu pengetahuan ibu yang baik ada 5 ibu (25\%) dan pengetahuan ibu yang cukup ada 15 ibu (75\%) hasil ini menunjukkan bahwa pengetahuan ibu tentang ASI masih kurang. Setelah diberikan penyuluhan hasil yang didapatkan yaitu pengetahui ibu yang baik ada $15 \mathrm{ibu}(75 \%)$ dan pengetahuan 
ibu yang cukup ada 5 ibu (25\%). Sehingga dapat disimpulkan, pengetahuan ibu tentang ASI eksklusif meningkat setelah diberikan penyuluhan.

\section{SIMPULAN}

Hampir rata-rata ibu tidak menyusui sampai 6 bulan dengan alasan air susu yang tidak lancar pengeluarannya. Setelah diberikan penyuluhan tentang ASI eksklusif ibu-ibu menjadi paham dan mengerti apa itu ASI eksklusif dan manfaatnya bagi ibu dan bayi. Saat diberikan soal setelah penyuluhan sebanyak $75 \%$ pengetahuan ibu cukup karena ibu menyimak saat diberikan penyuluhan dan adanya rasa ingin tahu dari ibu sendiri. Ini membuktikan sebagai petugas kesehatan perlunya edukasi yang seluas-luas nya kepada masyarakat terutama bagi ibu yang menyusui.

\section{DAFTAR PUSTAKA}

1. Hegar.Manajemen Laktasi.Jakarta: EGC Depkes RI.2008

2. Hegar.Manajemen Laktasi. Jakarta: EGC Depkes RI.2011

3. Yohmi, Roesli.Mengenal ASI Eksklusif Seri Satu.Jakarta.2009

4. Astuti, Sri. Pelatihan Konseling Menyusui.Jakarta: Direktur Jenderal Bina Kesehaan Masyarakat. 2007

5. Pillitry.Maternal and Child Health.Jakarta: EGC.2013

6. Sri Indarawati.Hubungan Asi Eksklusif dengan Kejadian Stunting di Desa Karangrejek Wonosari Gunung Kidul.Universitas ‘Aisyiyah.Yogyakarta.Tesis.2013 